\title{
Serratia marcescens Healthcare-Associated Ventriculitis and Cerebral Abscess in a Neonate with Chiari II Malformation: A Case Report and Systematic Review
}

\author{
Jeffrey I. Lappay, MD, ${ }^{1}$ Mairre James S. Gaddi, MD² and Loudella V. Calotes-Castillo, MD ${ }^{1}$ \\ ${ }^{1}$ Division of Pediatric Neurology, Departments of Pediatrics and Neurosciences, Philippine General Hospital, University of the Philippines Manila \\ ${ }^{2}$ Division of Neurosurgery, Department of Neurosciences, Philippine General Hospital, University of the Philippines Manila
}

\begin{abstract}
Serratia marcescens is a recognized nosocomial opportunistic pathogen but rarely caused central nervous system infection especially in the neonates. Outbreaks have been documented in the neonatal intensive care units (NICU) and a higher incidence among those with surgical procedures. This review aims to describe a neonate with nonleaking lumbosacral myelomeningocele presenting with multiple pyogenic brain abscesses caused by $S$. marcescens admitted in a NICU. This review also presents a concise literature review discussing the potential risk factor involved, diagnostic measures and therapeutic possibilities. We present a neonate with Chiari II malformation admitted in the NICU developing S. marcescens ventriculitis after a lumbosacral myelomeningocele repair. With an empiric treatment of meropenem for one week, repeat ventricular cerebrospinal fluid analysis worsened and developed cerebral abscess as detected using cranial ultrasound. Ciprofloxacin was added and completed for six weeks with improved neurologic status. On a 6-month follow-up, sensorineural hearing loss, focal epilepsy and developmental delay were documented. A systematic review showed that prematurity and NICU outbreaks were among the most common risk factors for the central nervous system involvement of $S$. marcescens. Meropenem remains to be the antibiotic of choice adjunct with timely neurosurgical intervention. Brain abscess showed the worst prognosis among the neurologic sequelae.
\end{abstract}

Keywords: Serratia marcescens; Healthcare-Associated Ventriculitis; Chiari II Malformation

\section{INTRODUCTION}

Poster presented in the $11^{\text {th }}$ Child Neurology Society of the Philippines, Inc., Biennial Convention on October 1-3, 2018, in Manila, Philippines.

Corresponding author: Jeffrey I. Lappay, MD Division of Pediatric Neurology

Departments of Pediatrics and Neurosciences

Philippine General Hospital, University of the Philippines Manila

Taft Avenue, Ermita, Manila 1000

Email: jilappay@up.edu.ph
Serratia marcescens is a gram-negative microorganism from the Enterobacteriaceae family. It was previously considered an innocuous saprophyte in the last four decades becoming a significant opportunistic pathogen with the predisposition to healthcare-associated infection and resistance to the antibiotic armamentarium.

Hand-to-hand transmission by hospital personnel harboring the pathogen is the primary mode of transmission. Several epidemiologic studies have supported this finding through positive hand culture studies during hospital outbreaks. ${ }^{1-4}$ Patients factors identified include incapacitating clinical condition, prolonged hospital stay, frequent exposure to medical instrumentation and intervention necessitating direct contact with hospital personnel. ${ }^{5}$

Rarely associated with primary invasive infection, $S$. marcescens typically infects immunocompromised hosts. The most commonly documented among these nosocomial infection includes bacteremia, respiratory tract, catheter-related urinary tract infections, and post-operative 
patients. ${ }^{6,7}$ Harboring this pathogen often lead to prolonged hospitalization and other significant morbidity and mortality.

Particularly among the neonates, bacteremia and sepsis frequently lead to central nervous system infection (CNSI). This could pose a challenging conundrum since the involvement of the central nervous system typically starts with irritability or lethargy, signs seen in other severe infections for this age group. ${ }^{8}$ Brain abscess is an extremely rare life-threatening complication of CNSI among the neonates. Worldwide, Streptococcus spp. is still the most commonly identified etiology of brain abscess based on several publications while $S$. marcescens had been described as a causative agent in few reports.

This report aims to describe a term neonate with a Chiari II malformation presenting with pyogenic brain abscess caused by $S$. marcescens admitted in a neonatal intensive care unit (NICU) and to review concise literature discussing the potential risk factors involved, diagnostic measures and therapeutic possibilities.

\section{CASE}

A male full-term neonate was delivered to a 32-yearold G2P1(1001) Filipina via low segment cesarean section. The prenatal check-up was initiated in a private obstetrician and referred to our institution upon detecting fetal hydrocephalus and a lumbosacral mass for eventual delivery and management.

Upon an unremarkable delivery, the patient had a normal head circumference, a non-leaking lumbosacral mass, spontaneous voiding, and flaccid lower extremities. He was then admitted to the neonatal intensive care unit for observation.

$\mathrm{He}$ was referred to neurosurgery for definitive management. Initial cranial computed tomography (CT) scan showed ventriculomegaly and aqueductal stenosis with the lumbosacral myelomeningocele (LSM), a diagnosis of Chiari II malformation was verified. With normal preoperative diagnostics, surgical management was eventually planned out.

On the seventh day of life, repair of the LSM was done with oxacillin and ceftazidime as a preoperative antibiotic. An intraoperative ventricular cerebrospinal fluid (CSF) was sterile. Two days after the procedure, the antibiotics were discontinued. He was maintained in a prone position to minimize the soiling of the wound.

On the $14^{\text {th }}$ day of life, the head circumference was noted to be increasing with new-onset fever and lethargy. A cranial ultrasound (CUTS) showed bilateral ventriculomegaly and septations on the right ventricles. A repeat ventricular tap showed hypoglycorrhachia, high protein and pleocytosis (Table 1). The isolate showed $S$. marcescens with sensitivity to meropenem, ciprofloxacin, and resistance to second and third-generations cephalosporin. He was then started on a meningitic dose and regimen of meropenem as advised by the infectious disease specialists.

Serial ventricular tap and cranial CT scans were conducted to ensure the activity of the antimicrobial agents (Table 1). In the first week of meropenem, CSF study showed an increased protein and pleocytosis hence a right tube ventriculostomy was inserted and Ciprofloxacin was added.

The patient had a focal seizure and repeat imaging showed right frontal abscess (Figure 1) on the second week of antibiotics. He was started on Phenobarbital at $5 \mathrm{mg} / \mathrm{kg} /$ day. With an improving ventricular CSF picture, meropenem and ciprofloxacin were completed for six weeks. A ventriculoperitoneal shunt was inserted in the right frontoparietal area.

Post-treatment, the patient had a close follow-up at the outpatient service. Gross and fine motor developments were

Table 1. Trends of cerebrospinal fluid studies through repeated ventricular tap and antibiotics administered

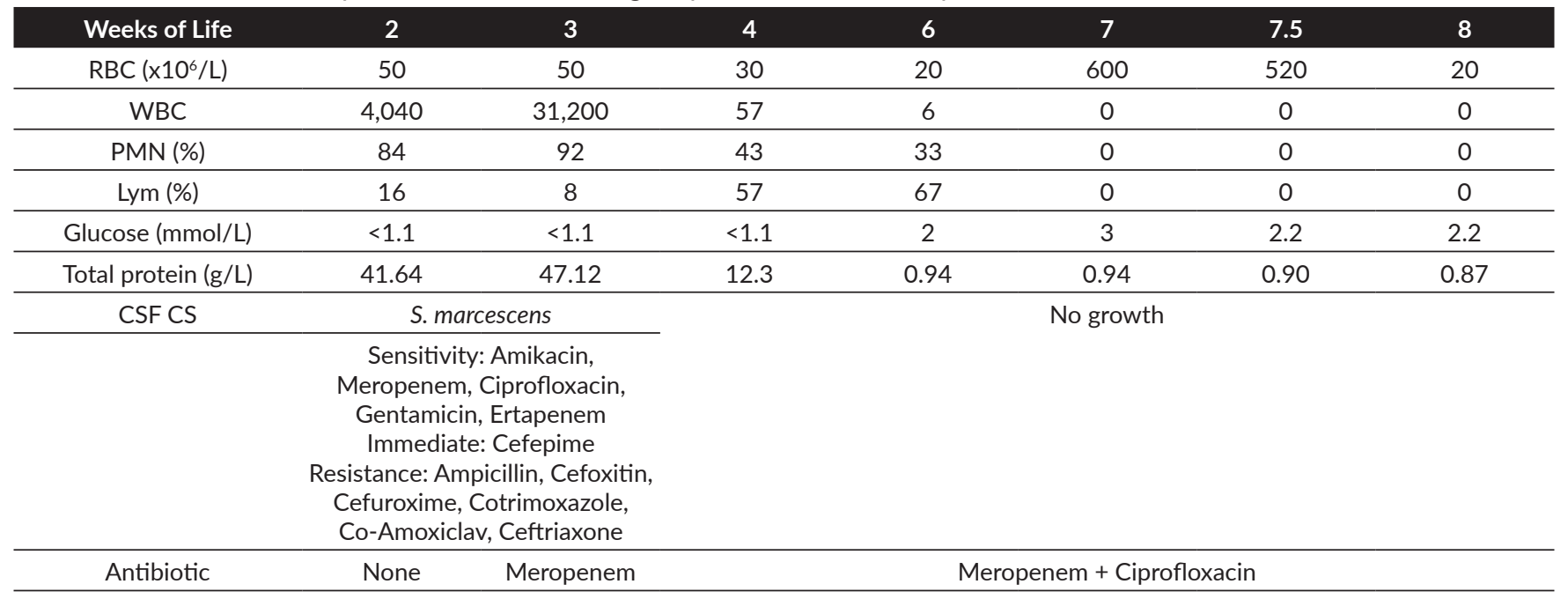

$R B C=$ red blood cell; $W B C=$ white blood cell; $P M N=$ polymorphonuclear Lym = lymphocyte; $C S F=$ cerebrospinal fluid; $C S=$ culture sensitivity 

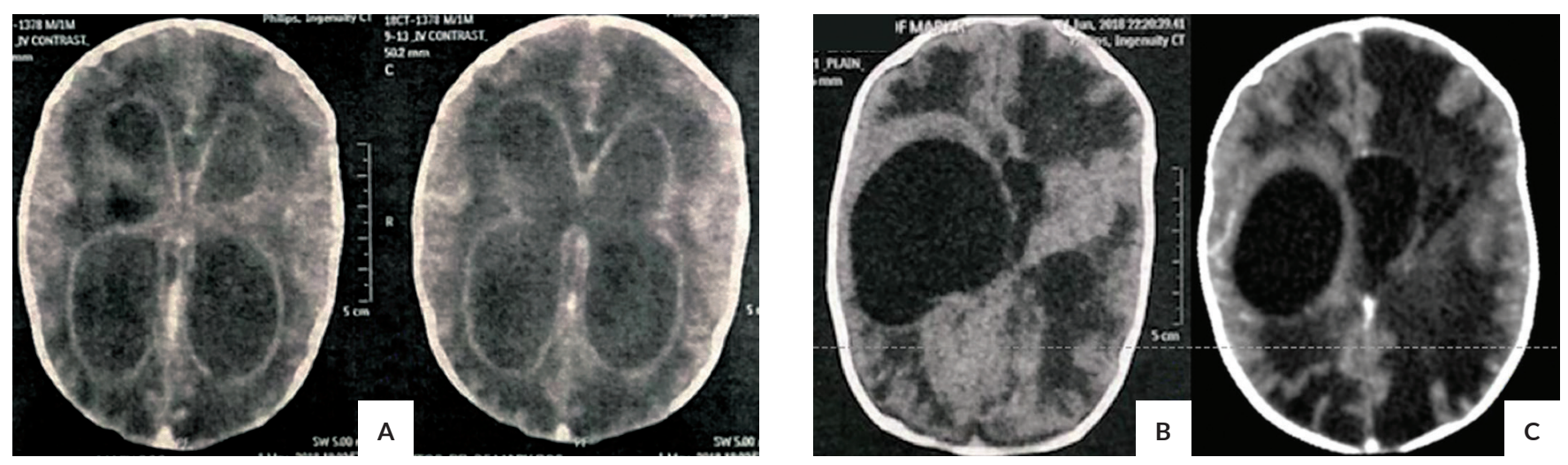

Figure 1. Serial Cranial CT scan imaging. (A) Imaging before the start of treatment showing signs of ventriculitis, the hyperdense focus at the right frontoparietal region and hydrocephalus. (B) Imaging was done on 2nd week of antibiotics, (C) and the $6^{\text {th }}$ week of antibiotics.

delayed. Head circumference was initially within normal limits for age until four months when the anterior fontanels were bulging. The cranial CT scan showed an enlarging ventricle on the left hence an additional shunt was inserted on the left posterior parietal area.

An electroencephalogram (EEG) was done on the third month of life showing rare right frontal epileptiform discharges hence the antiepileptic drug was continued after discharge. In the $6^{\text {th }}$ months of life, a repeat EEG already showed occasional multifocal epileptiform discharges at the right prefrontal and central regions as well as the bilateral parieto-temporal areas (FP2, C4, P3/P4, T5/T6). Oxcarbazepine at $15 \mathrm{mg} / \mathrm{kg} /$ day was started.

On neurologic examination, he had visual tracking but unable to localize to sound. Motor testing showed spastic upper extremities. A brainstem auditory evoked potential was done suggestive of bilateral sensorineural hearing loss. The kidney and urinary bladder ultrasound were also normal. He was referred to as developmental pediatrics and rehabilitation medicine for early intervention.

Informed consent was obtained before the reporting of this case.

\section{DISCUSSION AND SYSTEMACTIC REVIEW}

Outbreaks of Serratia marcescens had been documented in the neonatal intensive care units but did not often lead to central nervous system infections and other complications. S. marcescens and cerebral infections were usually linked to cerebral instrumentation like neurosurgical procedures or in some instances even as simple as lumbar puncture. ${ }^{9}$

Our case is a neonate with nonleaking lumbosacral myelomeningocele. International recommendations indicate that a delivered neonate with myelomeningocele should receive surgical repair of the defect within 24 to 48 hours to lessen the likelihood of infection. ${ }^{10}$ Such care is not always attainable in low-income countries. Those with the ruptured defect are usually prioritized than those with non-leaking LSM as described in this report.

In earlier studies involving newborns with myelomeningocele, preoperative broad-spectrum antibiotic therapy decreased the likelihood of developing ventriculitis to $1 \%$ (from 19\% who received non-broad-spectrum antibiotics). ${ }^{11}$ The incidence of ventriculitis was attributed more to the wound breakage and CSF leakage at the site of repair than the actual delay in closure. ${ }^{12}$

The choice of preoperative antibiotic, oxacillin, and ceftazidime, was based on the institutional biogram of the neonatal intensive care unit recommended by the hospital infection control unit. With the traditional low intrinsic pathogenicity of $S$. marcescens, a third-generation cephalosporin should have been adequate as a coverage together with other Enterobacteriaceae microbes.

Recent studies, however, suggest tissue penetration of S. marcescens via cytotoxicity and emission of inflammatory mediators associated with pore-forming hemolysin, ShIA. This pathogenic extracellular product has also been associated with a widespread pathogenic pathway in bacterial swarming and quorum sensing. ${ }^{13,14}$ Also, isolates of these micro-organisms had been recognized to produce biofilms that contribute to its pathogenicity. ${ }^{15}$

Reports on pediatric patients with CNS involvement of $S$. marcescens is summarized in Table 2. A total of twelve studies were included in the systematic reviews retrieved from PubMed, Embase, and HERDIN. No local literature was identified in the literature search. Several outbreaks in the neonatal ICU were published in the English literature however, CNS involvement was not documented. Only two outbreaks were included in this review.

Prematurity and neonatal ICU admission are the two main risk factors associated with $S$. marcescens CNS involvement in this systematic review. In the series of reviews, no pediatric patient with the neurosurgical procedure has been documented yet. ${ }^{16}$ 
Table 2. Summary of Central Nervous System Involvement of Serratia marcescens among pediatric patients

\begin{tabular}{|c|c|c|c|c|}
\hline Author $\&$ Country $/$ Year $/ \mathrm{n}=$ & Underlying condition & Antibiotic Therapy & $\begin{array}{l}\text { Surgical Procedures } \\
\text { or Instrumentation }\end{array}$ & $\begin{array}{c}\text { Complications / Sequalae } \\
\text { (Remarks) }\end{array}$ \\
\hline $\begin{array}{l}\text { Nagle }^{17} \text { et al. in USA } \\
1986,(n=1)\end{array}$ & $\mathrm{ICH}$ & $\begin{array}{l}\text { Cefoxitin (49d) + } \\
\text { amikacin (19d) }\end{array}$ & $\begin{array}{l}\text { Abscess UTS-guided } \\
\text { drainage (twice) }\end{array}$ & Mild sequalae \\
\hline $\begin{array}{l}\text { Lam }^{18} \text { et al. in Australia } \\
1993,(n=4)\end{array}$ & $\begin{array}{l}\text { Prematurity (3), ARDS (2) } \\
\text { DORV+ASD (1) }\end{array}$ & $\begin{array}{l}\text { Penicillin }+ \\
\text { Chloramphenicol }\end{array}$ & None & $\begin{array}{l}\text { Late-onset brain abscess (1) } \\
\text { Brain abscess (1) } \\
\text { Ventriculitis (1) } \\
\text { Mortality (2) }\end{array}$ \\
\hline $\begin{array}{l}\text { Ries }^{19} \text { et.al (NM) } \\
1993,(n=2)\end{array}$ & Sepsis and IVH & $\begin{array}{l}\text { Cefotaxime }+ \\
\text { Tobramycin }\end{array}$ & $\begin{array}{l}\text { External CSF drainage, } \\
\text { VPS }\end{array}$ & $\begin{array}{l}\text { Brain abscess, moderate } \\
\text { hypotonia (1) } \\
\text { Mortality (1) }\end{array}$ \\
\hline $\begin{array}{l}\text { Kimpen }^{20} \text { et al. (NM) } \\
\text { 1996, }(n=1)\end{array}$ & Prematurity and sepsis & Ceftazidime + Amikacin & None & None \\
\hline $\begin{array}{l}\text { Berger }^{21} A(N M) \\
2002,(n=3)\end{array}$ & $\begin{array}{l}\text { Prematurity, } \\
\text { RDS, Sepsis, Seizure }\end{array}$ & $\begin{array}{l}\text { Meropenem + } \\
\text { Amikacin / Fosfomycin } \\
\text { (1) } \\
\text { Cefotaxime + Amikacin } \\
\text { (1) } \\
\text { Ciprofloxacin + } \\
\text { Cefepime (1) }\end{array}$ & VPS (1) & $\begin{array}{l}\text { Good sequalae for } \\
\text { Ciprofloxacin + Cefepime } \\
\text { Moderate sequalae for } \\
\text { Meropenem + Amikacin / } \\
\text { Fosfomycin } \\
\text { Severe sequalae for } \\
\text { Cefotaxime + Amikacin }\end{array}$ \\
\hline $\begin{array}{l}\text { Sung }{ }^{22} \text { et al. in South Korea } \\
2006,(n=24)\end{array}$ & NICU outbreak & $\begin{array}{l}\text { Imipenem, Bactrim, } \\
\text { Amikacin }\end{array}$ & None & $\begin{array}{l}\text { Meningitis }(1 / 24) \\
\text { Brain Abscess }(1 / 24)\end{array}$ \\
\hline $\begin{array}{l}\text { Hirooka }{ }^{23} \text { et al. in Brazil } \\
2007,(n=1)\end{array}$ & $\begin{array}{l}\text { Prematurity, twin } \\
\text { gestation, PDA, NEC }\end{array}$ & Meropenem (60d) & None & Rupture of brain abscess \\
\hline $\begin{array}{l}\text { Polilli24 et al. in Italy } \\
2011,(n=4)\end{array}$ & $\begin{array}{l}\text { Outbreak } \\
\text { Premature (3) } \\
\text { ARDS (4) } \\
\text { Sepsis (3) }\end{array}$ & & None & $\begin{array}{l}\text { (Culture positive of two } \\
\text { soap dispensers and } \\
\text { human surfaces) }\end{array}$ \\
\hline $\begin{array}{l}\text { de Albuquerque }{ }^{25} \text { et al. in Portugal } \\
2012,(n=1)\end{array}$ & $\begin{array}{l}\text { Prematurity, ARDS and } \\
\text { ASD }\end{array}$ & Meropenem & $\begin{array}{l}\text { Direct needle aspiration } \\
\text { of brain abscess }\end{array}$ & Brain abscess \\
\hline $\begin{array}{l}\text { Ivady }{ }^{26} \text { et al. in Hungary } \\
2014,(n=14)\end{array}$ & $\begin{array}{l}\text { Prematurity and IRDS (2); } \\
\text { Prematurity, IUGR, ARDS, } \\
\text { NEC, PDA (1) }\end{array}$ & NM & None & $\begin{array}{l}\text { Meningitis }(3 / 14) \\
\text { Brain abscess }(1 / 3) \\
\text { Mortality }(1 / 3) \\
\text { (One culture of a water } \\
\text { tap sample) }\end{array}$ \\
\hline $\begin{array}{l}\text { Madie \& Smith }{ }^{27} \text { in South Africa } \\
2016,(n=5)\end{array}$ & $\begin{array}{l}\text { Congenital HIV (1), } \\
\text { Prematurity (5) }\end{array}$ & Meropenem & None & $\begin{array}{l}\text { HIE (1) } \\
\text { Brain abscess (5) } \\
\text { Mortality (3) }\end{array}$ \\
\hline $\begin{array}{l}\text { Aires }^{28} \text { et al. in Brazil } \\
2016,(n=1)\end{array}$ & $\begin{array}{l}\text { Prematurity, twin } \\
\text { gestation, sepsis }\end{array}$ & Meropenem & $\begin{array}{l}\text { Epicutaneous-cava } \\
\text { catheter }\end{array}$ & Mortality \\
\hline
\end{tabular}

$N M=$ not mentioned; ICH = intracerebral hemorrhage; UTS = ultrasound; ARDS = acute respiratory distress syndrome; DORV = double outlet right ventricle; $A S D=$ atrial septal defect; IVH = intraventricular hemorrhage; IUGR = intrauterine growth restriction; NEC = necrotizing enterocolitis; $P D A=$ patent ductus arteriosus

In the study of Madie and Smith, the role of cranial ultrasound (CUTS) was analyzed among five neonates with S. marcescens intracranial infection. They postulated that the initial changes of $S$. marcescens brain abscess represented areas of ischemic injury. These areas later progress to infarction and liquefaction. The cysts visualized will then represent abscess formation within the brain parenchyma. An urgent CUTS is recommended in neonates who unexpectedly deteriorate clinically. Follow-up imaging within 7-14 days will also aid in determining the extent of injury and planning of surgical intervention if warranted. ${ }^{27}$

In the earlier years, the Enterobacteriaceae family were traditionally given beta-lactam drug in combination with a second non-beta-lactam agent such as aminoglycosides because these antibiotics have a high-level AmpC (chromosomal beta-lactamase-producing strains) coverage. However, recent studies showed that broad-spectrum cephalosporins such as cefotaxime, ceftazidime, ceftriaxone, and cefepime are becoming weak inducers of the enzyme with the possibility of AmpC de-repression [sic]. Fourthgeneration cephalosporin, carbapenems, and piperacillintazobactam are now becoming treatment options. ${ }^{29}$

At present, no standardized diagnostics is available for determining AmpC. Resistance to Cefoxitin had been used as a surrogate marker for $\mathrm{AmpC}$ production but this test is not specific as some Class A beta-lactamases and some carbapenemases can mediate this resistance as well. ${ }^{30}$ 
With increasing resistance to the typical antibiotic regimen for S. marcescens, Meropenem has now become the initial drug of choice. The use of meropenem has resulted in a better outcome for infected patients particularly those with debilitating conditions admitted in an intensive care unit. One study suggested a prolonged infusion of meropenem for three hours divided into doses yielded a better CNS penetration and resulted in remission od CNS symptoms after 4 days. $^{31}$

On the other hand, in S. marcescens outbreaks, chromosomal and plasmid-mediated carbapenemase had been identified discouraging the use of meropenem and other carbapenems. In this clinical context, fluoroquinolones may provide better coverage for this serious $S$. marcescens infection. $^{32}$

Combination antimicrobial therapies, particularly for the multi-drug resistance gram-negative micro-organisms, is recommended. With the growing resistance to the usual combination, a study of Ermertcan et. al showed that a synergistic effect of meropenem and ciprofloxacin combination was more effective than given singly against Pseudomonas aeruginosa. ${ }^{33}$ This case demonstrated the same synergistic effect of this combination in the treatment of $S$. marcescens health-care-associated ventriculitis and cerebral abscess.

Aside from a timely neurosurgical intervention and rational use of antibiotics, enforcement of strict infection control protocols whenever $S$. marcescens colonization is discovered in the NICU is equally important to prevent outbreaks and other deteriorating cascades.

Few publications have reported the long-term effects of the $S$. marcescens CNS involvement. In addition to brain abscess and ventriculitis, cerebral edema with increased intracranial pressure, cerebritis, hydrocephalus, and subdural effusion or empyema were noted. ${ }^{34-36}$ This case report, showed initial 6-month surveillance of a healthcareassociated $S$. marcescens ventriculitis and cerebral abscess post-treatment and surgical procedure.

\section{CONCLUSION}

Serratia marcescens is a rare but important cause of health-care-associated ventriculitis and cerebral abscess among neonates admitted in the neonatal ICU. A term neonate with lumbosacral meningocele developing these complications after the repair of the defect was reported. Cranial UTS is a cost-effective and reliable screening tool for early detection of ventriculitis and abscess. Simultaneous use of meropenem and ciprofloxacin showed a synergistic effect in the treatment of $S$. marcescens ventriculitis and cerebral abscess as observed in multi-drug resistant Pseudomonas aeruginosa. Immediate neurosurgical intervention is likewise tantamount to patient improvement. Neurologic sequelae include sensorineural hearing loss, hydrocephalus, focal epilepsy, and developmental delay.

\section{Statement of Authorship}

All authors participated in data collection and analysis, and approved the final version submitted.

\section{Author Disclosure}

All authors declared no conflicts of interest.

\section{Funding Source}

This paper is self-funded.

\section{REFERENCES}

1. de Vries JJ, Baas WH, van der Ploeg K, Heesink A, Degener JE, Arends JP. Outbreak of Serratia marcescens colonization and infection traced to a healthcare worker with long-term carriage on the hands. Infect Control Hosp Epidemiol 2006; 27: 1153-8

2. Maki DG, Hennekens CG, Phillips CW, Shaw WV, Bennett JV. Nosocomial urinary tract infection with Serratia marcescens: an epidemiologic study. J Infect Dis 1973; 128: 579-87.

3. Hejazi A, Aucken HM, Falkiner FR. Epidemiology and susceptibility of Serratia marcescens in a large general hospital over an 8-year period. J Hosp Infect 2000;45:42-6.

4. Ivanova D, Markovska R, Hadjieva N, Schneider I, Mitov I, Bauernfeind A. Extended-spectrum beta-lactamase-producing Serratia marcescens outbreak in a Bulgarian hospital. J Hosp Infect 2008; 70:60-5.

5. van der Sar-van der Brugge S, Arend SM, Bernards AT, Berbee GA, Westendorp RG, Feuth JD, van den Broek PJ. Risk factors for acquisition of Serratia marcescens in a surgical intensive care unit. J Hosp Infect 1999; 41:291-9.

6. Maki DG, Hennekens CG, Phillips CW, Shaw WV, Bennett JV. Nosocomial urinary tract infection with Serratia marcescens: an epidemiologic study. J Infect Dis 1973; 128: 579-87.

7. Yu VL. Serratia infection in the surgical patient. Infect Surg 1984;3:127-34

8. Bentlin MR, Rugolo LMSS. Late-onset sepsis: epidemiology, evaluation and outcome. NeoReviews. 2010;11(8):e426-35.

9. Moehring R. Infections due to Serratia species. Available at: http:// www.uptodate.com/ contents/infections-due-to-serratia- species, last access: October 2015.

10. Punt J (2001) Surgical management of neural tube defects. In: Levene MI, Chervenak FA, Whittle MJ (eds) Fetal and neonatal neurology and neurosurgery. Churchill Livingstone, London, Edinburgh, New York, pp 753-73

11. Charney EB, Melchionni JB, Antonucci DL (1991) Ventriculitis in newborns with myelomeningocele. Am J Dis Child 145:287-90

12. Volpe J (2001) Neural tube formation and prosencephalic development. In: Volpe J (ed) Neurology of the newborn. WB Saunders, Philadelphia, pp 3-44

13. Lai HC, Soo PC,Wei JR, Yi WC, Liaw SJ, Horng YT, Lin SM, Ho SW, Swift $\mathrm{S}, \mathrm{W}$ illiams $\mathrm{P}$. The RssAB two-component signal transduction system in Serratia marcescens regulates swarming motility and cell envelope architecture in response to exogenous saturated fatty acids. J Bacteriol 2005; 187:3407-14.

14. Lin CS, Horng JT, Yang CH, Tsai YH, Su LH, Wei CF, Chen CC, Hsieh SC, Lu CC, Lai HC. RssAB-FlhDC-ShlBA as a major pathogenesis pathway in Serratia marcescens. Infect Immun 2010; 7:4870-81.

15. Shanks RM, Stella NA, Kalivoda EJ, Doe MR, O'Dee DM, Lathrop KL, Guo FL, Nau GJ. A Serratia marcescens OxyR homolog mediates surface attachment and biofilm formation. J Bacteriol 2007;189: 7262-72.

16. Wu YM, Hsu PC, Yang CC, Chang HJ, Ye J-Jr, Huang CT, et al. Serratia marcescens meningitis: Epidemiology, prognostic factors and treatment outcomes. J Microbiol Immunol Infect 2013 Aug;46(4): $259-65$. 
17. Nagle RC, Taekman MS, Shallat RF, Cohen RA. Brain abscess aspiration in nursery with ultrasound guidance: case report. J Neurosurg 1986;65:557-9.

18. Lam H, Berrl A, Desilva M, Will G, Lam A. Intracranial Serratia infection in preterm newborn infants. AJNR July/August 1984; 5 : 447-51.

19. Ries M, Deeg KH, Heininger U, Stehr K. Brain abscesses in neonates: report of three cases. Eur J Pediatr 1993;152:745-6.

20. Kimpen JL, Brus F, Arends JP, de Vries-Hospers HG. Successful medical treatment of multiple Serratia marcescens brain abscesses in a neonate. Eur J Pediatr 1996;155:916.

21. Berger A, Rohrmeister K, Haiden N, Assadian O, Kretzer V, Kohlhaus- er C. Serratia marcescens in the neonatal intensive care unit: re-emphasis of the potentially devastating sequelae. Wien Klin Wochenschr 2002;114:1017-22.

22. Sung MJ, Chan CH, Yoon YK, Park SE. Clinical aspects of an outbreak of Serratia marcescens infections in neonates. Korean J Ped 2006; 500-6.

23. Hirooka TM, Fontes RB, Diniz RM, Pinto FC, Matushita, H. Cerebral abscess caused by Serratia marcescens in a premature neonate. Arq Neuropsiquiatr 2007;65(4-A):1018-21.

24. Polilli E, Parruti G, Fazii P, D'Antonio D, Palmieri D, D'Incecco C, Mangifesta A, Garofalo G, Del Duca L, D’Amario C, Scimia M. Rapidly controlled outbreak of Serratia marcescens infection/ colonisations [sic] in a neonatal intensive care unit, Pescara General Hospital, Pescara, Italy, April 2011.

25. de Albuquerque R, Bean L, de Paula RS, Meguins LS. Pyogenic brain abscess caused by Serratia marcescens in a Brazilian premature neonate: case report. J Bras Neurocirurg 2012; 23 (1): 65-8

26. Ivády B, Szabó D, Damjanova I, Pataki M, Szabó M, Kenesei É. Recurrent outbreaks of Serratia marcescens among neonates and infants at a pediatric department: an outbreak analysis. Infection 2014 Oct;42(5):891-8. doi: 10.1007/s15010-014-0654-9. Epub $2014 \mathrm{Jul} 12$.
27. Madie A, Smith J. Intracranial complications of Serratia marcescens infection in neonates. Afr Med J 2016;106(4):342-4. doi:10.7196/ SAMJ.2016.v106i4.10206.

28. Aires S, Frutuoso S, Carvalho C. S. marcescens sepsis with brain involvement: a fatal outcome. J Pediatr Neonat Individual Med 2016;5(1):e050137 doi: 10.7363/050137

29. Harris PN, Ferguson JK. Antibiotic therapy for inducible AmpC betalactamase-producing Gram-negative bacilli: what are the alternatives to carbapenems, quinolones and aminoglycosides? Int J Antimicrob Agents 2012; 40: 297-305.

30. Jacoby GA. AmpC beta-lactamases. Clin Microbiol Rev 2009; 22: 161-82.

31. Nicasio AM, Quintiliani RJr, DeRyke CA, Kuti JL, and Nicolau DP. Treatment of Serratia marcescens Meningitis with Prolonged Infusion of Meropenem. Ann Pharmacother 2007 June; 41 (6): 1077-81.

32. Cai JC, Zhou HW, Zhang R, Chen GX. Emergence of Serratia marcescens, Klebsiella pneumoniae, and Escherichia coli isolates possessing the plasmid-mediated carbapenem-hydrolyzing betalactamase $\mathrm{KPC}-2$ in intensive care units of a Chinese hospital. Antimicrob Agents Chemother 2008; 52: 2014-8.

33. Ermertcan S, Tünger O, CoŞar G, Mine HoŞgör. Investigation of synergism of meropenem and ciprofloxacin against Pseudomonas aeruginosa and Acinetobacter strains isolated from Intensive Care Unit Infections. Scand J Infect Dis 2001; 33 (11): 818-21.

34. Bentlin MR, Rugolo LMSS. Late-onset sepsis: epidemiology, evaluation and outcome. NeoReviews. 2010;11(8):e426-35.

35. Edwards M. Bacterial meningitis in the neonate: neurologic complications. Available at: http://www.uptodate.com/contents/ bacterial-meningitis-in-the-neonate-neurologic-complications, last access: October 2015.

36. Philip AGS. Neonatal meningitis in the new millennium. NeoReviews. 2003;4(3):e73-80. 